\title{
Bee flora resources and honey production calendar of Gera Forest in Ethiopia
}

\author{
TURA BAREKE ${ }^{\nu}$, ADMASSU ADDI \\ Oromia Agricultural Research Institute, Holeta Bee Research Center, Ethiopia, P.O. Box 31, West Showa Zone, Oromia Region, Ethiopia.
}

Tel.: +251-112370376, Fax.: +251-112370377, `email: trbareke@ gmail.com

Manuscript received: 18 October 2019. Revision accepted: 13 November 2019.

\begin{abstract}
Bareke T, Addi A. 2019. Bee flora resources and honey production calendar of Gera Forest in Ethiopia. Asian J For 3: 69-74. Gera forest, Ethiopia contains substantial coverage of natural forest and is known as a Key Biodiversity Hotspot area for Coffea arabica conservation and one of the potential areas for beekeeping. The study was carried out to assess the bee flora and flowering calendar that produce more honey following the flowering plant cycle. Semi-structured questionnaires, participatory Rural Appraisal (PRA) techniques, and field observation were used for data collection. Honey samples collection was also made to identify the botanical origin of honey through honey pollen analysis. Seventy-four bee plant species were identified which belong to 41 families. Among the identified plant families, Asteraceae (29.3\%), Lamiaceae (14.6\%), Acanthaceae (12.2\%), and Fabaceae (9.8\%) were the most frequent families represented by the highest species composition in the area. Four major honey harvesting durations were identified (J anuary, March, April, and early June for Vernonia, Coffee, Schefflera, and Croton honey respectively) using the flowering calendar in Gera Forest. The pollen analysis of honey revealed that four types of monofloral honey were identified comprising Schefflera abyssinica, Vernonia amygdalina, Coffea arabica, and Croton macrostachyus in Gera forest. This is due to their abundance and potentiality for honey production. Therefore, the beekeepers should follow the flowering calendar of the plant to exploit the potential of the forest for honey production. Furthermore, market promotion for monofloral honey of the Gera forest should be made as an incentive for the beekeepers to sell honey with premium prices and branding and labeling of honey of the area
\end{abstract}

Keywords: Bee forage, floral calendar, honey, monofloral honey, pollen analysis

\section{INTRODUCTION}

Ethiopia has a great potential for beekeeping development. The ideal climatic conditions, diversified floral resources, and huge water bodies allow the country to sustain around 10 million honeybee colonies (Amssalu et al. 2004). Beekeeping contributes to food security through pollination, economic and natural resource conservation, and creating better employment opportunities (Admassu et al. 2014a; Tura et al. 2014; EIAR 2016; Tura et al. 2018; Tura and Admassu 2019a). Despite the great opportunity in beekeeping and honey production, the beekeepers in Ethiopia have not yet well benefited from the subsector. This is mainly attributed to the inadequate introduction of improved technologies and skills that enhances the quantity and quality of bee products. Currently, Oromia Region contributes the highest for honey production in Ethiopia with $41 \%$ of the total honey production of the country (CSA, 2015). The Oromia region represents approximately $70 \%$ of the forest resources of the country, yet its closed high forests are diminishing due to shifting cultivation, fuelwood collection, urbanization, and logging (CSA 2015).

Gera forest is one of the remaining forest resources in the southwestern part of Oromia. The Gera forest contains substantial coverage of natural forest and is known as a Key Biodiversity Hotspot Area for Coffea arabica conservation and potential area for beekeeping (Kitessa
2007). Apart from its dense natural forest, the district is dominated by agroforestry comprised of spices plants and fruit trees. As a result, a large volume of honey is produced annually. In addition to this, honey is an important source of income for smallholder farmers in the area (Chala et al. 2012). Even though the forest has a lot of major bee flora, the beekeepers of the area could not understand the flowering calendars of the honeybee plants.

A flowering calendar is a timetable for a beekeeper that indicates the approximate date and duration of the blossoming periods of the important honey and pollen plants (Diver 2002; Tura and Admassu 2018). Knowledge of seasonal availability, length of flowering, and flowering phenology of honeybee plants is very important to boost the production of honey. The seasonal cycles of honeybee colonies are related to the calendar of bee plants in such a way that it will be applied in practical seasonal colony management (Fichtl and Admassu 1994; Admassu et al. 2014b; Tura and Admassu 2018). The timing of management operations corresponding to a phenological pattern of bee plants of the area is critical in building up colony populations before the main nectar flow. Even though bees naturally build up their population during periods when resources are available, the beekeeper must ensure that peak population size before or during the nectar flow. Hence, the flowering calendar is an important tool for determining various beekeeping management operations, such as when to suppering and reduce, time of 
supplementary feed, insert queen excluder, transferring time, honey harvesting time, and honeybee colony migration time.

So far, there is limited information about honeybee plants and floral calendar of the Gera forest. Therefore, the main objective of this study was to assess honeybee plants and flowering calendar that enables the beekeepers to harvest honey sequentially following the seasonal flowering cycle.

\section{MATERIALS AND METHODS}

\section{Study area}

Gera Forest is located in Gera District approximately $100 \mathrm{~km}$ to the west of Jimma, located in the southwestern part of Ethiopia. Gera forest consists of undulating hills at the altitudinal ranges of $1,000-3,000 \mathrm{~m}$ with steep mountainous terrain in some places (Bruk 2015). It has a total area of 80,830.4 ha (Yohannes et al. 2015). The soil in the forest is dystric nitosol type, which is deep, clay-red soil (GDARDO 2012). The mean annual temperature is about $18.4^{\circ} \mathrm{C}$, while the mean annual rainfall is $1805 \mathrm{~mm}$ (NMSA 2013). Gera Forest contains a number of flowering plant species that are endemic to Ethiopia. Based on the published Flora of Ethiopia, seven endemic species have been identified (Yohannes et al. 2015). In the Gera forest, there are five plant communities, namely Vernonia auriculifera-Prunus africana community type, Schefflera abyssinica-Maytenus arbutifolia community type, Coffea arabica-Olea capensis community type, Syzygium guineense-Galiniera saxifraga community type and Croton macrostachyus-Albizia gummifera community type (Yohannes et al. 2015).

\section{Data collection}

Primary data was collected using semi-structured questionnaires, participatory Rural Appraisal (PRA) techniques, and field observation. The focus group discussions with experts, development agents and beekeepers were conducted to generate relevant information. The information focused on honey production potential, major honey source plants, major honey types, honey harvesting periods, and frequency and honey yield per hive. Field observation was made on bee floras of the forest to identify the plant and the food source provided for bees during the flowering period. A total of 12 pure honey samples (3 samples per harvesting month) were collected during honey flow seasons that have a similar climatic condition. Accordingly, December to February (January), March to May (March and April), and June August (start of June) from the farm gate of the beekeepers. For each honey collection site, three honey samples were purchased. Each honey sample was weighed $500 \mathrm{~g}$. The samples were then stored at $4^{\circ} \mathrm{C}$ for further analysis (Tura and Admassu 2019b).

\section{Honey pollen analysis}

For honey pollen analysis, the method recommended by the International Commission for Bee Botany (Louveaux et al. 1978) was adopted. Ten grams of each honey was dissolved in $20 \mathrm{ml}$ of warm water $\left(40^{\circ} \mathrm{C}\right)$. The solution was centrifuged for $10 \mathrm{~min}$ at $2500 \mathrm{r} / \mathrm{min}$, the supernatant solution was decanted, and the sediments were collected into a conical tube for the study (Erdtman 1960). The sediments were rinsed with distilled water to enhance further extraction of pollen from honey, centrifuged for 5 $\mathrm{min}$ at $2500 \mathrm{r} / \mathrm{min}$, and preserved for study. To analyze the pollen content of the honey samples, two slides were prepared from each sample, and the picture of the pollen was taken by the camera connected to the microscope (Carl ZEISS microscope Germany). Pollen types were identified by comparison with reference slides of pollen collected directly from the plants in the study area. For quantification of the pollen types, at least 500 pollen grains were counted from each sample (Oliveira et al. 2010). The percentage frequency of the pollen taxa in all the samples was calculated, excluding polleniferous plant species, which were observed during honey pollen analysis. The types of pollen were allocated to one of four frequency classes for nectar source plants: predominant pollen types $(>45 \%$ of the total pollen grains counted); secondary pollen types (16\%-45\%); important minor pollen types (3\%-15\%); and minor pollen types (3\%) (Louveaux et al. 1978). Honey with predominant pollen types was considered as monofloral. Finally, descriptive statistics were used to analyze the collected data.

\section{RESULTS AND DISCUSSION}

\section{Pollen analysis of honey}

The pollen analysis of honey from 12 monofloral honey of the Gera forest indicated that 13 plant species were identified, ranging from $2 \%$ to $60 \%$ of the pollen count. The monofloral honey of $C$. arabica was contributed by four plant species (C. arabica, Vernonia amygdalina, Rumex spp, and Vernonia auriculifera (Figure 1). C. arabica honey is a new emerging monofloral honey in the area and produced in coffee agroforestry and forest coffee production system. It has a very short flowering period usually stays in flower for 5 to 7 days, and $C$. arabica honey is mostly harvested from February to March.

Vernonia honey was mainly dominated by $V$. amygdalina (Ebicha), and the pollen count from honey ranged from $1.9 \%$ to $50.4 \%$. The other bee forage plants contributing to Vernonia monofloral honey were Eucalyptus spp., C. arabica, Vernonia auriculifera (Rejji), and Caesalpinia decapetala (Figure 1). Vernonia honey is very dark in color even after crystallization, and it tends to granulate uniformly. The honey has a very strong flavor and bitter test, traditionally the honey is well known for its medicinal property (Admassu et al. 2014b). 


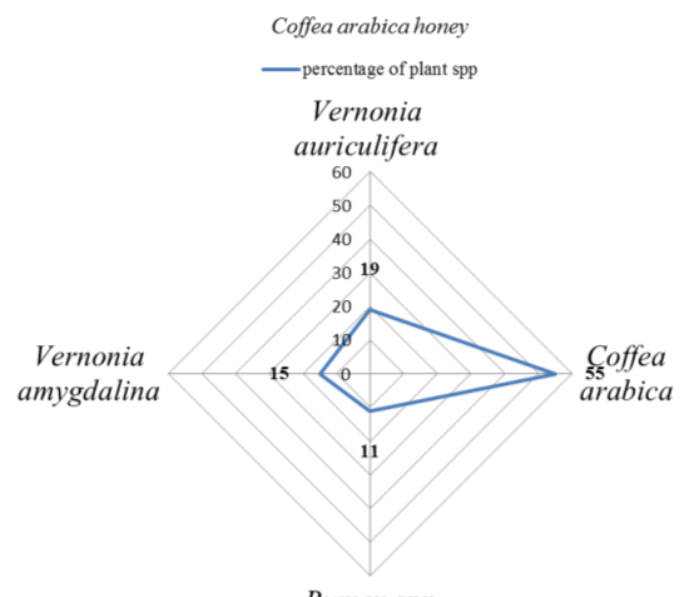

Rumex spp

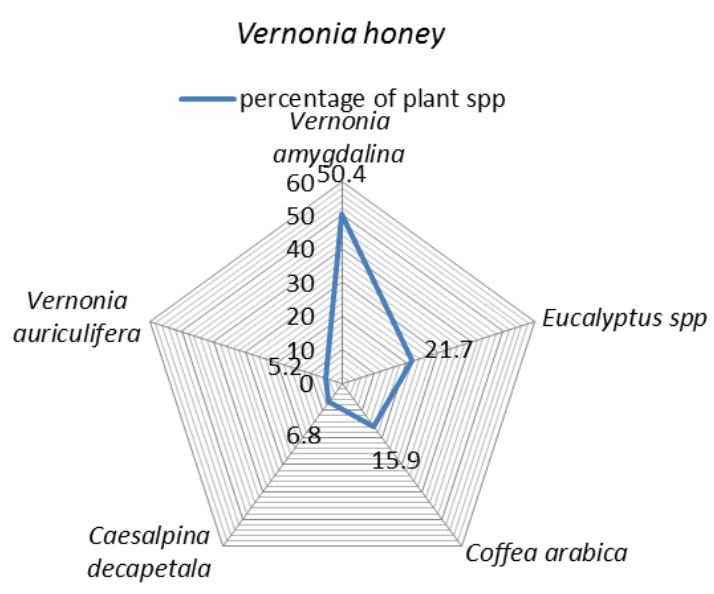

Figure 1. Pollen analysis of honey of Coffea arabica and Vernonia amygdalina honey with other species contributed for both honey in Gera forest, Ethiopia
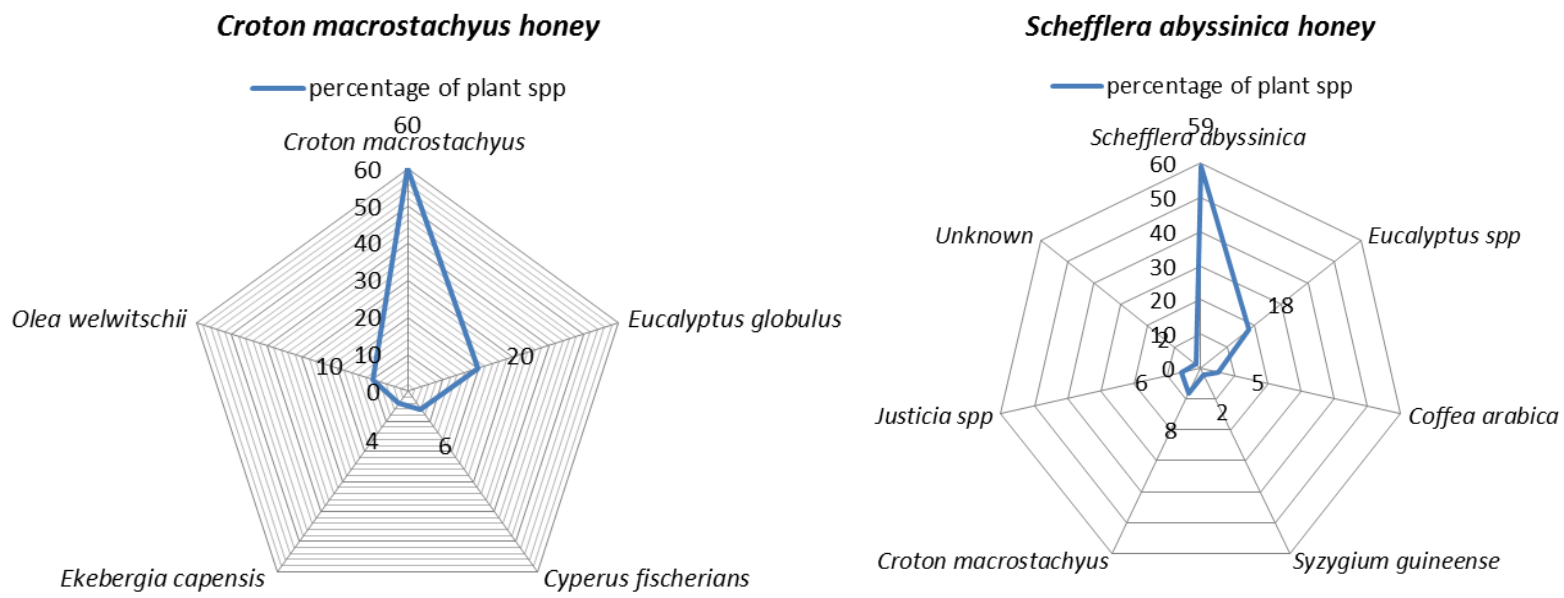

Figure 2. Pollen analysis of honey of Croton macrostachyus and Schefflera abyssinica honey with species contributed for both honey in Gera forest, Ethiopia

The honey of Schefflera was harvested from April to May after the minor rainy season. Schefflera honey was mainly dominated by Schefflera abyssinica. The pollen count from $S$. abyssinica honey ranged from $2 \%$ to $59 \%$ in which pollen count percentage of S. abyssinica was $59 \%$. C. arabica, Eucalyptus spp., Justicia spp., Syzygium guineense and Croton macrostachyus were other bee plants that contributed to this honey production (Figure 2). The honey from this plant is extra white with a characteristic aroma and a very pleasant test.

On the other hand, the honey of Croton was harvested in June at the end of the minor rainy season. Croton honey comprised 5 species of which C. macrostachyus, Eucalyptus globulus, Cyperus fischeriana, Ekebergia capensis, and Olea welwitschii are the species contributing to croton honey in which the highest pollen count percentage was the C. macrostachyus (60\%) (Figure 2). Monofloral honey of $S$. abyssinica and C. macrostachyus species were produced because of their abundance in addition to their potential for honey production. Tura and Admassu (2018) also reported that the dominancy of monofloral honey source plant species in honey samples was due to their abundance and nectar potentiality.

Pollen pictures of major bee flora plants that provide monofloral honey in the Gera forest are presented in Figure 3.

\section{Bee flora resources in Gera forest}

The result of the study revealed that 74 honeybee forages were identified which belong to 41 families. Among the identified plant families, Asteraceae (29.3\%), Lamiaceae (14.6\%), Acanthaceae (12.2\%), and Fabaceae $(9.8 \%)$ were the most frequent families, represented by the highest species composition in the area. Admassu and Tura (2019) also reported that Asteraceae, Acanthaceae, Fabaceae, Rubiaceae, Poaceae, Lamiaceae, and 
Euphorbiaceae are the most frequent families, represented by the highest number of bee forage species (Table 1). However, a study conducted by Yohannes et al. (2015) in the Gera forest indicates that the Fabaceae family was the most dominant while Asteraceae was the second dominant. All species of Fabaceae family are not bee forage plants. Due to this, it is not a dominant honeybee plant family in the Gera forest. On the other hand, the dominance of the Asteraceae family could be attributed to the potential of its species for honey production. The life forms of bee forages showed that herbs represented the highest floristic composition, $35.1 \%$ followed by shrubs and trees $25.7 \%$ each, and climbers/lianas were $10 \%$. The dominance of herbs is due to disturbance and the presence of canopy gaps in the forest. The dominance of herbaceous flora was also reported by Ensermu and Teshome (2008), and Yohannes et al. (2015).

\section{Flowering season bee flora resources}

Eighty-one percent of honeybee plant species in the Gera forest were flowered from September to November, followed by March to May (10.8\%) and December to February (6.8\%) (Figure 4). Even though many honeybee plant species were flowered from September to November, monofloral honey was harvested from December to February and March to May in the Gera forest. This is because $72.5 \%$ percent of flowered honeybee plant species from September to November were provided pollen for honeybees. Whereas, the majority of flowered honeybee plant species from March to May and December to February were provided nectar of $56.25 \%$ and $50 \%$, respectively (Figure 4). Pollen is used to increase the population of the bee colony, while nectar is used for honey production. Thus, the number of nectar sources is very important to produce honey.

The presence of a higher number of flowering herbaceous plant species from September to November is due to the availability of moisture following the main rainy season, which lasts from June to August. This is in agreement with a study conducted by Tura and Admassu (2018) in the Guji zone of the Oromia region which indicated that herbaceous honeybee forage species were the dominant honey source plants from September to November. On the other hand, the second flowering period occurs after a small rainy season, which starts from March to May, in which the majority of honey source plants were trees and shrubs in comparison to herbaceous. For example, the tree species such as S. abyssinica, Syzygium guineense, C. macrostachyus, and Eucalyptus spp. are flowered in this season (Tura and Admassu 2018). Admassu et al. (2014b) also stated that $S$. abyssinica, Syzygium guineense, and $C$. macrostachyus are the most important honey-producing trees and flowers from April to March to April and hence the major honey flow period in southwest parts of Ethiopia occurred during March-June. The lower number of flowering plants was observed from June to August, which is the main rainy season throughout the country and plants tends to produce more vegetative biomass rather than producing flowers and the high scarcity of honeybee forage was observed in July to mid of August (Tura and Admassu 2018). This is in agreement with a similar study in central parts of Ethiopia (Debissa and Admassu 2009) reported that during the rainy season, low temperatures possibly inhibit flower production.

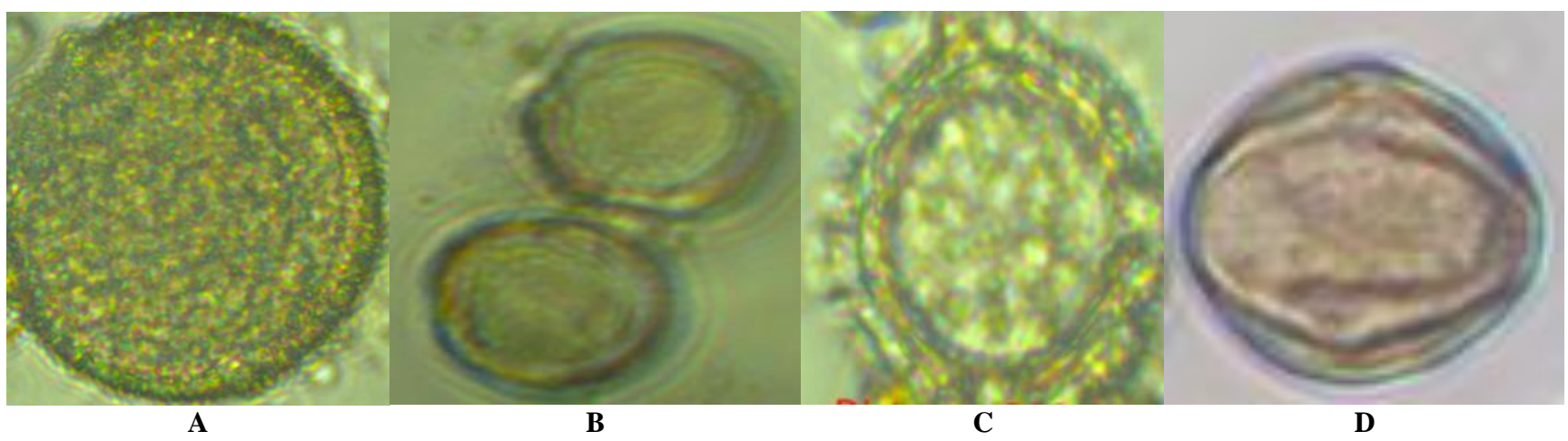

Figure 3. Pollen pictures of some major bee flora that provide monofloral honey in Gera forest, Ethiopia. A. Croton macrostachysyus, B. Schefflera abyssinica, C. Vernonia amygdalina, D. Coffea arabica 
Table 1. Bee forage plants with their family, habit, flowering period and food source for honeybees in Gera forest

\begin{tabular}{|c|c|c|c|c|c|}
\hline Family & Plant species & Local name (A/Oromo) & Habit & Flowering period & Rewards \\
\hline Acanthaceae & Acanthopale ethio-germanica & Gosa dergu & Herb & Sept-Nov & Nectar \& Pollen \\
\hline Acanthaceae & Acanthus eminens & Korati Boye & Herb & Sept-Nov & Nectar \\
\hline Acanthaceae & Hypoestes triflora & Dargu & Herb & Sept-Oct & Pollen \\
\hline Acanthaceae & Isoglossa somalensis & Gosa dergu & Herb & Sept-Nov & Nectar \& Pollen \\
\hline Acanthaceae & Justicia schimperiana & Dumuga & Climber & Sept-Nov & Nectar \& Pollen \\
\hline Amaranthaceae & Achyranthes aspera & Maxxanne & Herb & Sept-Dec & Pollen \\
\hline Aquifoliaceae & Ilex mitis & Hangadhi & Tree & Sept-Oct & Pollen \\
\hline Araliaceae & Polyscias fulva & Tul'a & Tree & Sept--Nov & Nectar \& Pollen \\
\hline Araliaceae & Schefflera abyssinica & Gatama & Tree & March-Apr & Nectar \\
\hline Arecaceae & Phoenix reclinata & Zambaba & Tree & Sept-Nov & Pollen \\
\hline Asclepiadaceae & Periploca linearifolia & Borino & Climber & Sept-Nov & Pollen \\
\hline Asteraceae & Acmella caulirhiza & Yemidir berbere & Herb & Sept-Nov & Pollen \\
\hline Asteraceae & Ageratum conyzoides & Introduced & Herb & Sept-Dec & Pollen \\
\hline Asteraceae & Aspilia mossambicensis & Arbi & Herb & Sept-Nov & Pollen \\
\hline Asteraceae & Bidens prestinaria & Kello & Herb & Sept-Nov & Pollen \\
\hline Asteraceae & Bothriocline schimperi & Shitto (Kafficho) & Herb & Sept-Dec & Pollen \\
\hline Asteraceae & Cirsium schimperi & Kore Harre & Herb & Sept-Oct & Pollen \\
\hline Asteraceae & Galinsoga quadriradiata & Abbadebo & Herb & Sept-Oct & Pollen \\
\hline Asteraceae & Guizotia scabra & Tufo & Herb & Sept-Nov & Nectar \& Pollen \\
\hline Asteraceae & Mikaniopsis clematoides & Kattisa & Climber & Sept-Nov & Pollen \\
\hline Asteraceae & Solanecio gigas & Nobe (Kafficho) & Herb & Sept-Nov & Pollen \\
\hline Asteraceae & Vernonia amygdalina & Ebicha & Shrub & Dec-Jan & Nectar \& Pollen \\
\hline Asteraceae & Vernonia auriculifera & Reji & Shrub & Dec-Jan & Nectar \& Pollen \\
\hline Basellaceae & Basella alba & Lebo & Climber & Sept-Oct & Pollen \\
\hline Boraginaceae & Cordia africana & Wadessa & Tree & Sept-Nov & Nectar \& Pollen \\
\hline Boraginaceae & Ehretia cymosa & Ulaga & Shrub & Sept-Nov & Nectar \& Pollen \\
\hline Brassicaceae & Brassica carinata & Rafu & Herb & Sept-Oct & Nectar \& Pollen \\
\hline Combretaceae & Combretum paniculatum & Begge & Climber & Sept-Nov & Pollen \\
\hline Dracaenaceae & Dracaena afromontana & Emmo (Kafficho) & Shrub & Sept-Nov & Nectar \& Pollen \\
\hline Euphorbiaceae & Croton macrostachyus & Bakkannisa & Tree & April-Jun & Nectar \& Pollen \\
\hline Fabaceae & Albizia gummifera & Mukarba & Tree & Sept-Oct & Nectar \& Pollen \\
\hline Fabaceae & Desmodium repandum & Silver leaf & Herb & Sept-Nov & Nectar \& Pollen \\
\hline Fabaceae & Glycine wightii & Gurra Hantuta & Climber & Sept-Nov & Pollen \\
\hline Fabaceae & Millettia ferruginea & Birbirra & Tree & Sept-Nov & Nectar \& Pollen \\
\hline Hypericaceae & Hypericum revolutum & Garamba & Shrub & Sept-Oct & Nectar \\
\hline Icaccinaceae & Apodytes dimidiata & Chalalaka & Tree & Sept-Nov & Nectar \& Pollen \\
\hline Lamiaceae & Achyrospermum schimperi & Bala dullacha & Herb & Sept-Nov & Pollen \\
\hline Lamiaceae & Plectranthus garckeanus & Gogoro & Herb & Sept-Nov & Nectar \& Pollen \\
\hline Lamiaceae & Plectranthus punctatus & Motijo (Kafficho) & Herb & Sept-Nov & Nectar \& Pollen \\
\hline Lamiaceae & Psycnostachys eminii & Ashoal (Hadiya) & Herb & Sept-Nov & Nectar \& Pollen \\
\hline Lamiaceae & Salvia nilotica & Sokoksa & Herb & Sept-Oct & Pollen \\
\hline Lamiaceae & Satureja paradoxa & Teneddam & Herb & Sept-Oct & Nectar \& Pollen \\
\hline Loganiaceae & Buddleja polvstachya. & Anfara & Shrub & Sept-Oct & Nectar \& Pollen \\
\hline Loganiaceae & Nuxia congesta. & Irba & Shrub & Sept-Nov & Nectar \& Pollen \\
\hline Lauraceae & Persea americana & Avocado & Tree & Sept-Nov & Pollen \\
\hline Meliaceae & Ekebergia capensis & Sombo & Tree & Jan-Feb & Nectar \& Pollen \\
\hline Melianthaceae & Bersama abyssinica. & Lolchisa & Tree & Sept-Nov & Nectar \& Pollen \\
\hline Myrsinaceae & Maesa lanceolata & Abayyi & Shrub & Sept-Oct & Pollen \\
\hline Myrtaceae & Eucalyptus globulus & Bargamo adi & Tree & Mar-April & Nectar \& Pollen \\
\hline Myrtaceae & Syzygium guineense & Badessa & Tree & Mar & Nectar \& Pollen \\
\hline Oleaceae & Olea capensis & Gagama & Shrub & April-May & Pollen \\
\hline Oleaceae & Olea welwitschii & Gosa Ejersa & Tree & April-May & Nectar \& Pollen \\
\hline Phytolaccaceae & Phytolacca dodocandra & Andode & Climber & Sept-Nov & Pollen \\
\hline Piperaceae & Piper capense & Turfo & shrub & Sept-Nov & Pollen \\
\hline Poaceae & Andropogon abyssinicus & Ballami & Herb & Sept-Oct & Pollen \\
\hline Ranunculaceae & Clematis simensis & Hidda fiti & Climber & Sept-Dec & Pollen \\
\hline Ranunculaceae & Ranunculus multifidus & Hogio (Kafficho) & Herb & Sept-Nov & Pollen \\
\hline Rhamnaceae & Gouania longispicata & - & Climber & Sept-Nov & Pollen \\
\hline Rhamnaceae & Rhamnus prinoides & Gesho & Herb & Sept-Nov & Pollen \\
\hline Rosaceae & Prunus africana & Homi/Gurra & Tree & Sept-Nov & Nectar \& Pollen \\
\hline Rosaceae & Rubus steudneri & Gora & Climber & Sept-Nov & Nectar \& Pollen \\
\hline Rubiaceae & Coffea arabica & Buna & Shrub & March & Nectar \& Pollen \\
\hline Rubiaceae & Galiniera saxifraga & Dido(Kef) & Shrub & Sept-Nov & Nectar \\
\hline Rutaceae & Clausena anisata & Ulumaya & Shrub & Sept-Dec & Nectar \& Pollen \\
\hline Rutaceae & Vepris dainellii & Hadhessa & Shrub & Dec-Jan & Pollen \& nectar \\
\hline Sapindaceae & Allophyllus abyssinicus & Sarara & Tree & Sept-Oct & Pollen \\
\hline Sapotaceae & Pouteria adolfi-friedericii & Keraro & Tree & April-May & Nectar \\
\hline Simaroubaceae & Brucea antidysenterica & Nukesho (Kafficho) & Shrub & Sept-Oct & Nectar \& Pollen \\
\hline Solanaceae & Brugmansia suaveolens & Ababo Turba & Shrub & Dec- Jan & Nectar \& Pollen \\
\hline Sterculiaceae & Dombeya torrida & Dannisa & Tree & Sept-Nov & Nectar \& Pollen \\
\hline Tiliaceae & Grewia ferruginea & Haroressa & shrub & Sept-Nov & Nectar \& Pollen \\
\hline Ulmaceae & Celtis africana & Amalakka & Shrub & Sept-Nov & Nectar \& Pollen \\
\hline Verbenaceae & Premna schimperi & Urgessa & Shrub & Sept-Oct & Nectar \& Pollen \\
\hline Zingiberaceae & Aframomum corrorima & Korrorima & Herb & Sept-Nov & Nectar \& Pollen \\
\hline
\end{tabular}



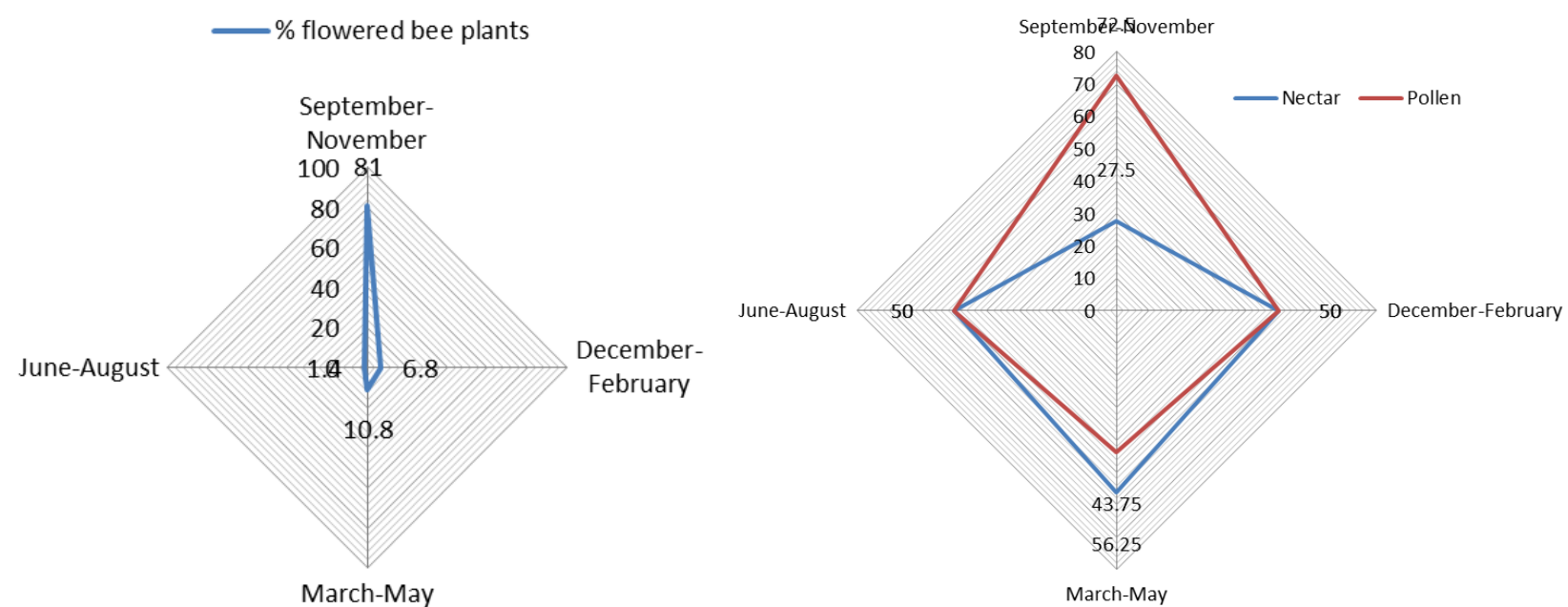

Figure 4. Percentage of flowered honeybee plant species in different major four seasons and food sources in Gera forest

In conclusion, from the identified bee forage plants, four plant species were produced monofloral honey due to their abundance and high nectar yielding potential of the species in the Gera forest. These were $S$. abyssinica, $C$. arabica, V. amygdalina, and C. macrostachyus. Majority of flowered bee forage plants were used for colony maintenance during October and November. On the other hand, at the end of December and start of January Vernonia honey was harvested; at the end of February and start of March Coffee honey was harvested; in mid-April or beginning May Schefflera honey was harvested; and at the start of June, Croton honey was harvested. July and August were identified as dearth periods due to heavy rain. Generally, the Gera forest has a high potential for honey production. Therefore, the beekeepers should follow the flowering calendar of $S$. abyssinica, $C$. arabica, $V$. amygdalina and $C$. macrostachyus to exploit the potential of the forest for honey production. Furthermore, market promotion for monofloral honey of the area should be made as an incentive for the beekeepers to sell honey at premium prices and branding and labeling of honey of the area.

\section{ACKNOWLEDGEMENTS}

The authors are thankful to the Forest-based food network project for providing the required facilities and logistics.

\section{REFERENCES}

Admassu A, Kibebew W, Amssalu A, Ensermu K. 2014b. Honeybee forages of Ethiopia. United Printers, Addis Ababa.

Admassu A, Kibebew W, Tura B. 2014a. Case study on contribution of beekeeping to the income generation of the households bordering Menagesha Suba State Forest. http://www.apitradeafrica.org/Documents/Technical Papers.

Admassu A, Tura B. 2019.Floral resources diversity of honeybees in important types of vegetation of Ethiopia. Asian J For 3 (2): 64-68. DOI: $10.13057 /$ asianjfor/r00300203

Amssalu B, Nuru A, Radloff SE, Hepburn HR. 2004. Multivariate morphometric analysis of honeybees (Apis mellifera) in the Ethiopian region. Apidologie 35: 71-81. DOI: 10.1051/apido:2003066

Bruk B. 2015. Floristic Composition and Vegetation Structure of Gera Moist Afromontane Forest, Jimma Zone of Oromia Regional State, Southwest Ethiopia. [Thesis]. Addis Ababa University, Addis Ababa.

Central Statistics Agency 2015. Federal Democratic Republic of Ethiopia Report On: Livestock and Livestock Characteristics (Private Peasant Holdings). Addis Ababa, Ethiopia.

Chala K, Taye W, Kebede D, Tadele T. 2012. Opportunities and challenges of honey production in Gomma district of Jimma zone, South-west Ethiopia. Addis Ababa University, Addis Ababa.

Debissa L, Admassu A. 2009. Identification and Evaluation of Bee Flora resources in arid and Semiarid Agroecological Zones of Southeast of Oromia. In proceedings of 17th Annual Conference of Ethiopia society of Animal production, Addis Ababa, Ethiopia.

Diver S. 2002. Phenology web links: Sequence of bloom, floral calendars, what's in bloom; birds, bees, insects and weeds. National Sustainable Agriculture Information Service. Washington, D.C., USA.

EIAR [Ethiopian Institute of Agricultural Research] 2016. Poultry, Fisheries, Apiculture and Sericulture Research strategy, Ethiopian Institute of Agricultural Research, Addis Ababa, Ethiopia

Ensermu K, Teshome S. 2008. Interfaces of Regeneration, structure, Diversity and uses of some plants species in Bonga Forest. A Reservoir for wild Coffee Gene Pool. SINET, Ethiopia J Sci 31: 121 134.

Erdtman G. 1960. The acetolysis method: a revised description. Seven Bot Tidskr 54: 561-564.

Fichtl R, Admassu A. 1994. Honey bee flora of Ethiopia. The National Herbarium, Addis Ababa University and Deutscher Entwicklungsdieenst (DED). Mergaf Verlag, Germany.

GDARDO [Gera District Agriculture and Rural Development Office] 2012. Socioeconomic profile of Gera District, Chira.

Kitessa H. 2007.Traditional Forest Management Practices in Jimma Zone, South West Ethiopia. Addis Ababa University, Addis Ababa.

Louveaux J, Maurizio A, Vorwohl G. 1978. Methods of Melissopalynology. Bee World 51 (3): 125-138. DOI: 10.1080/0005772X.1978.11097714

NMSA. 2013. Climadiagram of Chira town showing rainfall distribution and temperature variation from 2000 to 2010. National Meteorological Services Agency, Addis Ababa.

Oliveira PP, Van Den Berg C, Santos F. 2010. Pollen analysis of honeys from Caatinga vegetation of the state of Bahia, Brazil. Grana 49(1), 66-75. DOI: $10.1080 / 00173130903485122$

Tura B, Admassu A. 2018. Honeybee flora resources of Guji Zone, Ethiopia. J Biol Agric Healthcare 8 (21): 1-9.

Tura B, Admassu A. 2019a. Effect of honeybee pollination on seed and fruit yield of agricultural crops in Ethiopia. MOJ Ecol Environ Sci 4 (5): 205-209. DOI: 10.15406/mojes.2019.04.00155

Yohannes M., Tamrat B., Ensermu K. (2015). Floristic Composition, Species Diversity and Vegetation Structure of Gera Moist Montane Forest, Jimma Zone of Oromia National Regional State, Southwest Ethiopia. Ethiopian J Biol Sci 14 (1): 45-68. 